Historic, archived document

Do not assume content reflects current scientific knowledge, policies, or practices. 

Pacific Northwest Forest and Range

Experiment Station

Research Note

PNW-417

October 1984

\section{Estimating Cubic Volume ôf 0.991 Small Diameter Tree-Length Logs From Ponderosa and Lodgepole Pine}

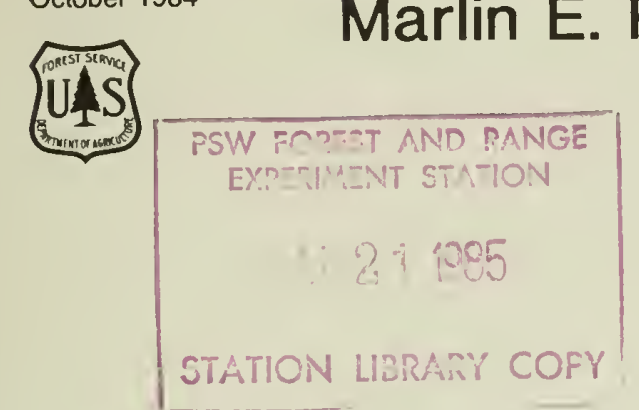

Abstract

Introduction
A sample of 351 ponderosa pine ( $P$ inus ponderosa Dougl. ex Laws.) and 509 lodgepole pine (Pinus contorta Dougl. ex Loud.) logs were used to evaluate the performance of three commonly used formulas for estimating cubic volume. Smalian's formula, Bruce's formula, and Huber's formula were tested to determine which would provide the best estimate of cubic volume when it was applied to tree-length logs. Smalian's formula overestimated the volume by 19 percent. Bruce's formula underestimated by 16 percent, and Huber's formula underestimated by 2 percent. Huber's formula provided the closest estimate and is recommended. Accuracy and bias tests are shown.

Keywords: Cubic volume, log volume, Smalian's formula, Huber's formula, Bruce's formula, scaling.

Coniferous trees have a central woody stem comprised of many geometric shapes (fig. 1). The geometric form of logs cut from these trees can vary depending on their position in the tree. Butt logs, for instance, approximate the shape of a concave paraboloid and logs cut from the middle of the tree, usually a convex paraboloid; logs cut from the top are either cones or paraboloids.

The geometric shape of a log dictates the formula to be used to estimate cubic volumes. Smalian's and Huber's formulas are often used to estimate the volume of midstem and upper-stem logs; both formulas assume a parabolic shape. Smalian's formula can also be used on butt logs after the large-end diameter has been reduced to account for basal flare. An equation developed by Bruce (1982) considers the neiloid shape of butt logs and estimates volume with no adjustment to the

MARLIN E. PLANK is a research forest products technologist and JAMES M. CAHILL is a research forester at Forestry Sciences Laboratory, P.O. Box 3890, Portland, Oregon 97208. 


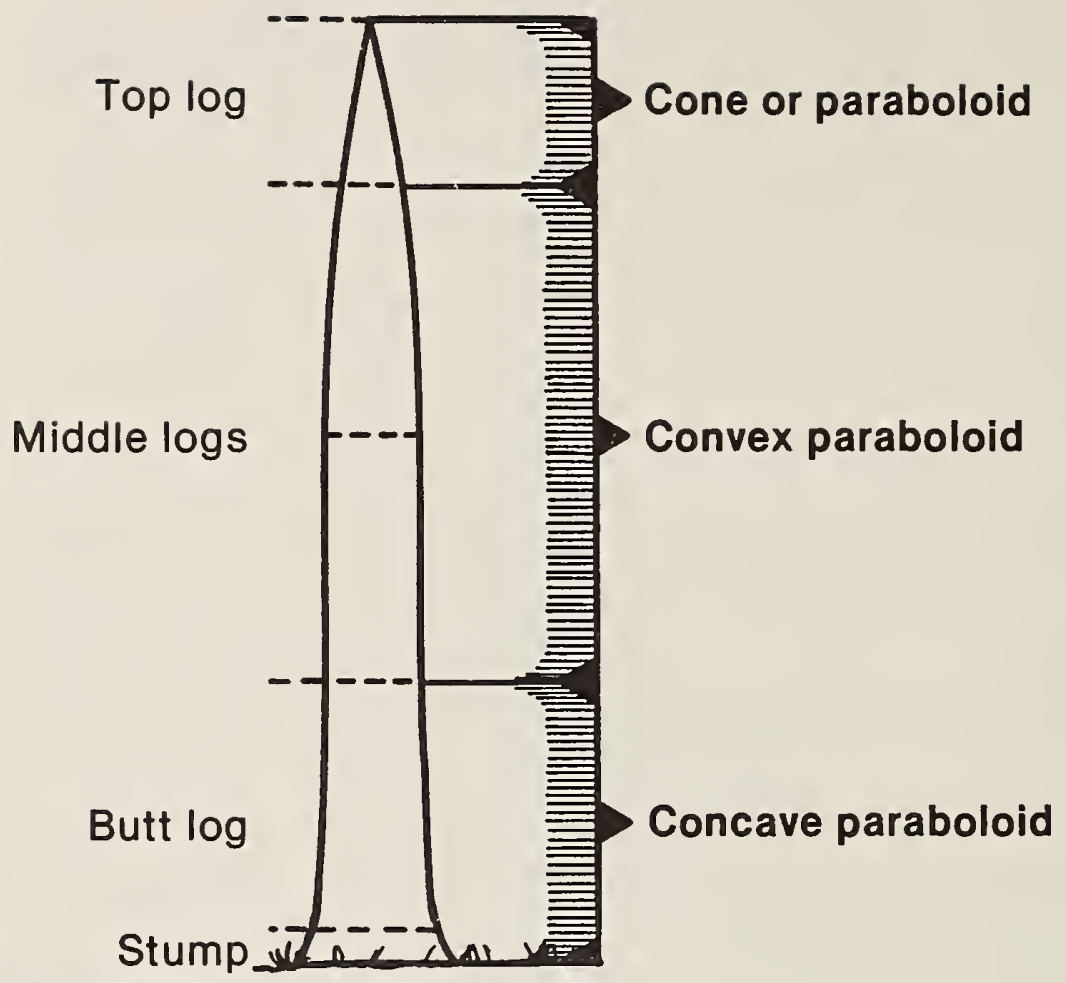

Figure 1--Geometric shapes in a coniferous tree stem.

measurement of the large end. Bruce's equation has proved accurate and unbiased 1 for coast Douglas-fir (Pseudotsuga menziesii (Mirb.) Franco var. menziesil) logs, and it is being evaluated by the forest products industry and the USDA Forest Service in the Western United States.

Selecting an accurate and unbiased formula to estimate the cubic volume of small diameter "tree-length" logs is difficult. Treelength logs usually extend from the stump into the live crown and can have the concave shape of the butt, the convex shape of the midstem, and the conic shape of the top within a single long log. The purpose of this paper is to compare the accuracy and bias of volume estimates made by Bruce's. Smalian's, and Huber's formulas on small diameter, tree-length ponderosa pine ( $P$ inus ponderosa Dougl. ex Laws.) and lodgepole pine ( $P$. contorta Doug1. ex Loud.) logs. None of these equations were designed specifically for tree-length logs, but because they are all in common use, knowledge of their accuracy will be helpful for scalers and mensurationists.

$\underline{1}$ Max, T. A.; Cahill, J. M. ; and Snellgrove, T. A. Validation of butt log estimator for Douglas-fir. Submitted to Forest Science in May 1984. 


\section{Methods}

\section{Data Base}

Log Measurements
The data used in this analysis were Scribner log scale measurements recorded on 860 tree-length logs. The sample included 351 ponderosa pine logs from Colorado, Arizona, and South Dakota, and 509 lodgepole pine logs from Wyoming and Oregon. The logs were from several product recovery studies. Generally, trees selected for product recovery studies include the range of stem quality that exists within a geographic area. We think these samples represent a good range of stem forms for small diameter ponderosa and lodgepole pine trees. The following tabulation shows the range of diameters and lengths for the tree-length logs in the sample: Number of
$\operatorname{logs}$
Ponderosa pine Lodgepole pine

$\frac{\text { Range in diameter }}{\text { Large Small }}$

(Inches)

$$
7-20 \quad 5-9
$$$$
\text { 6-18 4-10 }
$$

Range in length

(Feet)

Lengths and diameters of the tree-length logs were measured and recorded by USDA Forest Service scalers in the mill yard. After the logs were bucked for milling, the dimensions of the short logs were also recorded. Length of the short logs varied from 4 to 20 feet, depending on whether the $\log$ was processed into veneer ( $4 \mathrm{feet}$ ), studs ( $8 \mathrm{feet}$ ), or random-length dimension lumber ( 8 to 20 feet). All measurements were taken according to the USDA Forest Service Log Scaling Handbook (1973) rules.

Midpoint diameters were not directly measured on the logs in the data base. Estimates of the midpoint were made from the short log scale measurements as in the following example. For a 42-foot tree-length $10 g$ bucked into three short logs, the dimensions of the short logs are as follows:

Butt log: $16 \times 12$ inches $\times 16$ feet Middle log: $12 \times 9$ inches $\times 16$ feet Top log: $\quad 9 \times 6$ inches $\times 10$ feet

The midpoint of the tree-length $\log$ ( 21 feet) occurred in the second short $\mathrm{log}$. Diameters at each end of that $\mathrm{log}$ were 12 and 9 inches and the $\log$ length was 16 feet; the average taper was $(12-9) / 16=0.187$ inch per foot. Because the midpoint of the tree-length $\log$ was 5 feet from the large end of the second short $10 \mathrm{~g}$, the midpoint was estimated to be $12-(5 \times 0.187)=$ 11.1 inches. Midpoint diameters were rounded to the nearest inch. 
Computation of Actual Log Volume
For our purposes, actual volume of a tree-length $10 \mathrm{~g}$ is the sum of the cubic volumes of short logs bucked from the $10 g$. The majority of tree-length logs were cut into two or more segments and were processed into lumber. The volume of the butt segment was computed by Bruce's (1982) formula, and the volume of all other segments was computed by Smalian's formula. For the example shown above, the dimensions and volumes of the short logs are:

Butt log: ( $16 \times 12$ inches $\times 16$ feet) volume $=15.0$ cubic feet Middle log: ( $12 \times 9$ inches $\times 16$ feet $)$ volume $=9.8$ cubic feet Top log: ( $9 \times 6$ inches $\times 10$ feet $)$ volume $=3.2$ cubic feet

Actual volume of the tree--length $\log \left(v_{a}\right)$ is computed by summing the volumes of the short logs: $\mathrm{v}_{\mathrm{a}}=15.0+9.8$ $+3.2=28.0$ cubic feet.

To test whether a reasonable estimate of actual volume can be made by adding the volumes of short logs, we used 84 lodgepole pine logs from our data base; measurements had been taken at 4-foot intervals. If the sum of the volume for the 4-foot segments approximated the volume estimated for the entire short log, then our method of calculating short-log volume, and thus the tree-length volume, was accurate. We did not have similar measurements on the ponderosa pine and had to assume that the results of the lodgepole pine validation would apply to the ponderosa pine. The following procedure was used to make this test:

Each of the 84 tree-length $\operatorname{logs}$ was divided into a 16-foot butt $10 g$ and an upper $l o g$ of variable length. The actual volume for the shorter logs was computed by summing the volume of the 4-foot segments. The volume of each segment was computed by assuming that the segment was a frustum of a cone; that is, with the formula:

$v=\frac{0.005454}{3}\left(D_{s}^{2}+D_{L}^{2}+D_{s} D_{L}\right) L$

where:

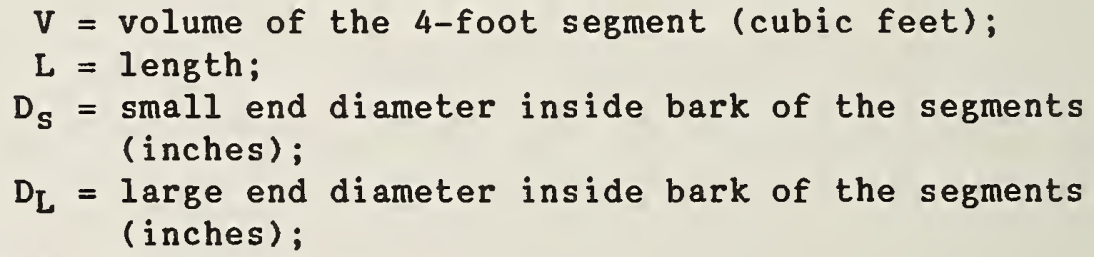


Computation of Estimated Volume
The volumes summed from the 4-foot segments were validated by comparing them with the estimates of the short-log volume computed by applying Bruce's (1982) formula on the butt 16-foot short-log segment and Smalian's formula on the top segment. For the 84 test $\operatorname{logs}$, we found that Bruce's equation underestimated the volume of the butt segments by an average of 5.3 percent, and Smalian's formula overestimated the volume of the top segments by an average of 0.4 percent. For the entire tree-length $10 \mathrm{~g}$, the estimated volume, obtained by summing the volumes of the short logs, underestimated the actual volume by 3 percent. We considered this an acceptable level of accuracy.

Estimated cubic-foot volumes of the tree-length logs were computed by Bruce's (1982), Huber's, and Smalian's formulas. The formulas are shown below:

Bruces's: Volume (cubic feet) $=0.005454\left(0.25 \mathrm{D}_{\mathrm{L}}{ }^{2}+0.75 \mathrm{D}_{\mathrm{s}}{ }^{2}\right) \mathrm{L}$; Huber's: Volume (cubic feet) $=0.005454\left(\mathrm{D}_{\mathrm{m}}^{2}\right) \mathrm{L}$;

Smalian's: Volume (cubic feet) $=0.0027274\left(D_{s}{ }^{2}+D_{L}{ }^{2}\right) L$;

where:

$\mathrm{L}$ is $\log$ length;

$D_{S}$ is small end diameter;

$D_{\mathrm{m}}$ is midpoint diameter:

$D_{L}$ is large end diameter;

and 0.005454 and 0.0027274 are conversion constants.

By use of the dimensions of the same tree-length $10 g$, the cubic-foot volumes estimated by the three formulas are:

Bruce's estimate: $\quad v_{b}=0.005454\left(0.75\left(6^{2}\right)+0.25\left(16^{2}\right)\right) 42.0$ $=20.8 \mathrm{ft}^{3}$.

Huber's estimate: $\quad v_{h}=0.005454\left(11^{2}\right) 42.0=27.7 \mathrm{ft}^{3}$.

Smalian's estimate: $v_{s}=0.0027274\left(6^{2}+16^{2}\right) 42.0=33.4 \mathrm{ft}^{3}$. 
Computation of Bias and Accuracy

\section{Results}

The deviations between actual volume $\left(v_{a}\right)$ and the three estimates of actual volume-- $\mathbf{V}_{b}, v_{h}$, and $v_{s}$--were computed for each log. The mean deviation was used to estimate the average bias for the ponderosa and lodgepole pine samples. The square root of the mean squared deviation was used as an estimate of accuracy. The computational formulas for bias and accuracy are shown below:

Bias $=\sum\left(\mathrm{V}_{\mathrm{a}}-\mathrm{V}_{\mathrm{e}}\right) / \mathrm{N}$;

Accuracy $=\left(\left[\left(\mathrm{v}_{\mathrm{Q}}-\mathrm{V}_{\mathrm{e}}\right)^{2 / N}\right)\right)^{\frac{1}{2}}$

where:

$v_{a}$ is the actual volume of a tree-length log;

$v_{e}$ is the volume estimated by either Bruce's, Smalian's, or Huber's formula; and

$\mathrm{N}$ is the number of logs in the sample.

Volume estimates made by Huber's formula had the least amount of bias and were the most accurate (table 1). This was consistent for the ponderosa and lodgepole pine data. On a percentage basis, Huber's formula underestimated the actual volume for both species combined by 2 percent, whereas Bruce's (1982) underestimated it by 16 percent and Smalian's overestimated it by 19 percent.

Table 1--Bias and accuracy of Huber's, Bruce's, and Smalian's formulas for predicting the cubic volume of ponderosa and lodgepole pine tree-length logs

Species

Bias

Huber $\begin{aligned} & \text { Bruce } \\ & (1982)\end{aligned} \quad$ Smalian

Accuracy

Huber Bruce Smalian

Cubic feet

Ponderosa

pine

0.39

3.20

$-5.31$

1.88

5.44

7.21

Lodgepole pine .38

$3.17-2.96$

1.72

4.39

4.32 
We recomend using Huber's formula for estimating cubic-foot volume for ponderosa and lodgepole pine tree-length logs. For our data, volume estimates made by Huber's formula were less biased and more accurate than estimates made by either Bruce's (1982) or Smalian's formula. Caution is necessary when these results are extrapolated beyond the range of diameters and lengths included in our samples.

Measuring only the midpoint diameter, as required by Huber's formula, has advantages and disadvantages. The obvious advantage is that only one diameter measurement is required on each $10 \mathrm{~g}$. This may represent a reduction in scaling costs. The disadvantages are: Scalers must have access to the middle of the log for caliper measurements, and estimates of bark thickness at the midpoint must be made. These are serious limitations if logs are scaled on trucks but would not be a problem when logs are rolled out in a yard. Finally, computing volumes by Huber's formula is easy and can be done directly in the field. Scalers need only log length and the midpoint diameter to obtain volume estimates by use of tables (USDA Forest Service 1978) of half cylinder cubic volumes.

Bruce, David. Butt $\log$ volume estimators. Forest Science. $28(3)$ : $489-503 ; 1982$.

U.S. Department of Agriculture, Forest Service. National Forest log scaling handbook. FSH 2409.11. Amend. 4. Washington, DC; 1973.

U.S. Department of Agriculture, Forest Service. Cubic scaling handbook. (A review draft.) Washington, DC; 1978. 
The Forest Service of the U.S. Department of Agriculture is dedicated to the principle of multiple use management of the Nation's forest resources for sustained yields of wood, water, forage, wildlife, and recreation. Through forestry research, cooperation with the States and private forest owners, and management of the National Forests and National Grasslands, it strives - as directed by Congress - to provide increasingly greater service to a growing Nation.

The U.S. Department of Agriculture is an Equal Opportunity Employer. Applicants for all Department programs will be given equal consideration without regard to age, race, color, sex, religion, or national origin.

Pacific Northwest Forest and Range

Experiment Station

319 S.W. Pine St.

P.O. Box 3890

Portland, Oregon 97208 